Gut, 1984, 25, 957-964

\title{
Optimal dose of oral omeprazole for maximal 24 hour decrease of intragastric acidity
}

\author{
B K SHARMA, R P WALT, R E POUNDER, M DE F A GOMES, \\ E C WOOD, AND L H LOGAN
}

From the Academic Department of Medicine, Royal Free Hospital School of Medicine, London

SUMmaRY In a series of 59 experiments in nine duodenal ulcer patients, 24 hour intragastric acidity was measured before, during, and after treatment with daily oral omeprazole. Omeprazole 10,20, and $30 \mathrm{mg}$ /day for one week caused a 37, 90, and 97\% decrease of 24 hour intragastric acidity, respectively. No further decrease of acidity was observed when the dose of omeprazole was doubled to $60 \mathrm{mg} / \mathrm{day}$, or after a second week of treatment with $30 \mathrm{mg} / \mathrm{day}$. One week after stopping treatment with omeprazole (14 doses) there was a significant $26 \%$ decrease of 24 hour intragastric acidity, with full recovery seven weeks later. Fasting plasma gastrin concentration was significantly raised during treatment with all doses of omeprazole. Omeprazole $30 \mathrm{mg} /$ day is the optimal dose for a maximal decrease of 24 hour intragastric acidity in duodenal ulcer patients.

Omeprazole is a substituted benzimidazole compound, one of a group of drugs which inhibit the parietal cell $\mathrm{H}^{+}, \mathrm{K}^{+}$-ATPase. ${ }^{1-8}$ This enzyme is thought to be the gastric proton pump which effects acid secretion at the parietal cell secretory membrane.

Initial studies with omeprazole have shown that it is a potent inhibitor of both basal and stimulated acid secretion in man, with a prolonged duration of action. ${ }^{9}$

Measurement of 24 hour intragastric acidity has been used successfully to observe the effects of other antisecretory drugs under conditions which approximate normal daily activity. ${ }^{10-13}$

We have already reported that oral omeprazole, $30 \mathrm{mg} /$ day for seven days, virtually eliminates 24 hour intragastric acidity in duodenal ulcer patients. ${ }^{14}$ That study has been extended in the same patients to compare the effects of different doses of omeprazole, to assess the drug's duration of action, and to relate observed changes of acidity to plasma gastrin and omeprazole concentrations.

\section{Methods}

PATIENTS

Nine male patients with a history of endoscopic:

Address for correspondence: Dr R E Pounder, Academic Department of Medicine. Royal Free Hospital, Pond Street, London NW3 2QC.

Received for publication 20 November 1983 ally-proven duodenal ulceration were studied during symptomatic remission. None took any other antisecretory drug for at least two weeks before the start of each study. Their mean age was 47.4 years (range 22-66 years) and their mean weight was $69 \cdot 2 \mathrm{~kg}$ (range $56.8-85.0 \mathrm{~kg}$ ). Five of the patients were cigarette smokers (mean 14/day).

\section{TWENTY FOUR HOUR INTRAGASTRIC ACIDITY}

The technique for measuring intragastric acidity has already been described. ${ }^{10-14}$ Intragastric acidity, from 0900-0800 hours the next day, was measured by hourly aspiration of $5-10 \mathrm{ml}$ of gastric contents through a nasogastric tube. The $\mathrm{pH}$ of the aspirates was measured to the nearest $0.01 \mathrm{pH}$ unit on the bench using a combined glass electrode which was calibrated before, during and after each group of hourly measurements using buffers of $\mathrm{pH} 1 \cdot 68,4.01$, and 7.00 (Radiometer, Copenhagen).

Identical meals, including beer or wine with lunch and dinner, were provided for each of the seven studies at $0915,1115,1315,1615,1915$, and 2215 hours. No snacks or drinks were taken between these meals. Cigarette smoking was allowed, but the same quantity and timing was repeated during all the studies.

\section{TREATMENT}

The patients were studied before, during, and after treatment with omeprazole. The omeprazole was always taken orally 15 minutes before breakfast as 
enteric coated granules in a hard gelatin capsule. To encourage compliance with this once daily regimen, the patients were each provided during the study with a Casio F-85 alarm chronograph wristwatch, which has a 24 hour alarm.

The design of the study is shown in the Table. All nine patients took part in the first five studies, but one was then excluded because of a possible adverse reaction to omeprazole ${ }^{14}$ two patients were unable to join the final study for personal reasons. The studies during treatment with omeprazole were performed after one or two weeks of treatment with the drug, the seventh or fourteenth doses being taken at 0900 hours on the morning of the respective studies. On day 14 of the study four patients had taken omeprazole $30 \mathrm{mg} /$ day for 14 doses, whereas five patients had taken omeprazole $30 \mathrm{mg} /$ day for seven doses followed immediately by omeprazole 60 $\mathrm{mg} /$ day for the next seven doses.

\section{PLASMA OMEPRAZOLE}

Blood samples were taken for estimation of plasma omeprazole concentration at 12 predetermined intervals throughout the 24 hours of each study. Plasma omeprazole was measured using high pressure liquid chromatography, after extraction into methylene chloride at $\mathrm{pH} 6.5$ to $7 \cdot 0$ (PO Lagerstrom, personal communication).

\section{PLASMA GASTRIN}

On each study day venous blood was taken for measurement of plasma gastrin concentration before breakfast, and at four half hourly intervals after the meal. Five millilitres of blood was added to $0.1 \mathrm{ml}$ of Trasylol (Bayer) in a lithium heparin glass tube. The plasma was separated immediately, and stored at $-20^{\circ} \mathrm{C}$ until all the samples were measured by radioimmunoassay (antibody Gas 179) in the same batch at the end of the study. ${ }^{15}$

SAFETY AND STATISTICS

A clinical examination and full laboratory profile of each patient was made before and after each course

Table Schedule of treatment

\begin{tabular}{rlll}
\hline $\begin{array}{l}\text { Day of } \\
\text { study }\end{array}$ & $\begin{array}{l}\text { Omeprazole } \\
\text { doselday }\end{array}$ & $\begin{array}{l}\text { Treatment } \\
\text { (wks) }\end{array}$ & $\begin{array}{l}\text { Patients } \\
\text { (no) }\end{array}$ \\
\hline 0 & none & & 9 \\
7 & $30 \mathrm{mg}$ & 1 & 9 \\
14 & $30 \mathrm{mg}$ & 2 & 4 \\
& $30 / 60 \mathrm{mg}$ & 2 & 5 \\
21 & none & 1 & 9 \\
70 & none & 8 & 9 \\
77 & $10 \mathrm{mg}$ & 1 & 8 \\
105 & $20 \mathrm{mg}$ & 1 & 6 \\
\hline
\end{tabular}

of treatment with omeprazole.

Written, informed consent was provided by each patient. The study was approved by the Ethical Committee of the Royal Free Hospital.

Statistical significance of observed differences in the acidity and gastrin data was assessed by two-way analysis of variance, after logarithmic transformation of the data.

\section{Results}

INTRAGASTRIC ACIDITY DURING TREATMENT

The mean hourly intragastric $\mathrm{H}^{+}$activity of the six patients who received each of the seven day courses of omeprazole $(10,20$, and $30 \mathrm{mg} /$ day $)$ is shown in Figure 1. There was a dose dependent decrease of acidity. Twenty four hour intragastric $\mathrm{H}^{+}$activity fell from $39.2 \pm 2.3 \mathrm{mmol} / \mathrm{l}$ (mean $\pm \mathrm{SEM}$ ) before treatment to $24.6 \pm 2.2 \mathrm{mmol} / \mathrm{l}$ (37\% decrease), $3.9 \pm 0.9 \mathrm{mmol} / \mathrm{l}(90 \%$ decrease $)$, and $1 \cdot 1 \pm 0.4 \mathrm{mmol} /$ 1 (97\% decrease) during treatment with omeprazole 10,20 , and $30 \mathrm{mg} /$ day, respectively. The differences between each of the regimens are significant $(p<0 \cdot 01)$. Figure 2 shows each patient's decrease of 24 hour intragastric acidity during treatment with different doses of omeprazole. It shows some between subject variability of response - in particular only four of eight patients responded to omeprazole $10 \mathrm{mg} /$ day.

A second week of treatment with either omeprazole $30 \mathrm{mg} /$ day (four patients) or $60 \mathrm{mg} / \mathrm{day}$ (five patients) decreased 24 hour intragastric $\mathrm{H}^{+}$ activity by $99 \%$ and $96 \%$ compared with the before treatment acidity, respectively. This decrease of acidity is not significantly different to the decrease of acidity observed at the end of one week of treatment with omeprazole $30 \mathrm{mg} /$ day.

\section{ACIDITY AFTER CESSATION OF TREATMENT}

A decrease of 24 hour intragastric acidity was observed in eight of the nine patients one week after the cessation of 14 days of treatment with omeprazole (Fig. 3). Mean 24 hour $\mathrm{H}^{+}$activity was $28.7 \pm 3.4 \mathrm{mmol} / \mathrm{l}$ (mean $\pm \mathrm{SEM}$ ) compared with $38.7 \pm 3.9 \mathrm{mmol} / \mathrm{l}$ before treatment. This $26 \%$ decrease of acidity is significant $(\mathrm{p}<0.001)$. Eight weeks after stopping omeprazole, mean 24 hour intragastric $\mathrm{H}^{+}$activity was $40.3 \pm 4 \cdot 1 \mathrm{mmol} / \mathrm{l}$ $(+4.0 \%$; Fig. 4). This is not significantly different to the before treatment intragastric acidity.

FASTING PLASMA GASTRIN

Figure 5 shows that at the end of one week of treatment with omeprazole $30 \mathrm{mg} / \mathrm{day}$, there was a rise of fasting plasma gastrin concentration in all the patients: mean plasma gastrin rose significantly from 
Fig. 1 Mean hourly intragastric $\mathrm{H}^{+}$activity before and during treatment with omeprazole 10,20, and $30 \mathrm{mg} /$ day. Seventh dose of omeprazole taken at 0900 hours.

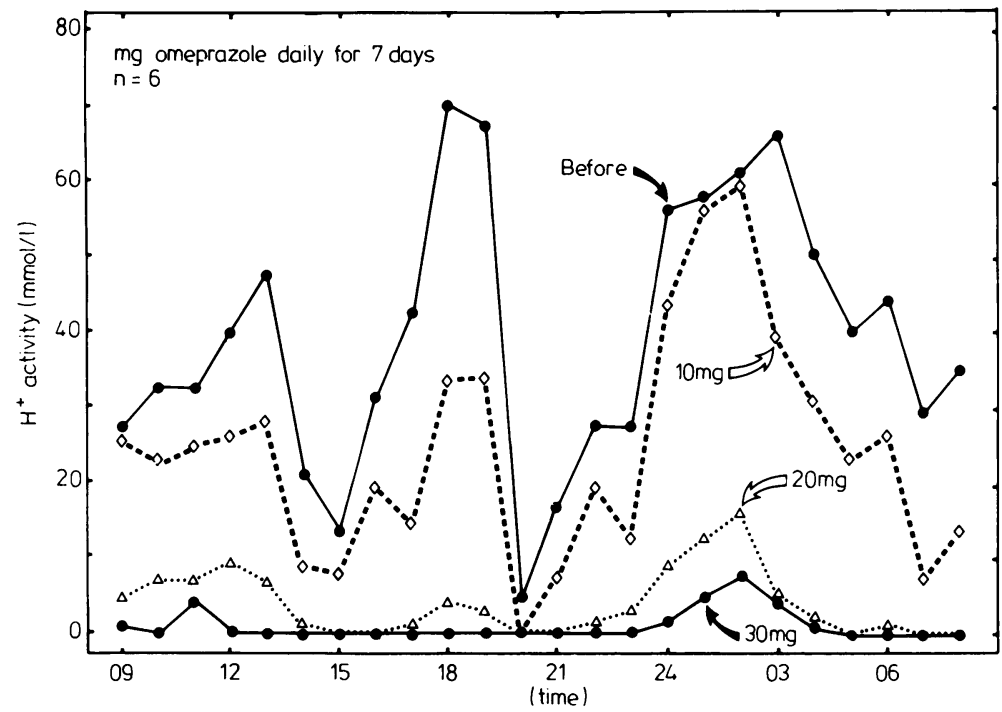

$7 \cdot 3 \pm 1 \cdot 2 \mathrm{pmol} / \mathrm{l}($ mean $\pm \mathrm{SEM})$ to $17 \cdot 4 \pm 2 \cdot 3 \mathrm{pmol} / \mathrm{l}$ $(p<0.001 ; n=9)$. During the second week of treatment with omeprazole 30 or $60 \mathrm{mg} /$ day, there was a further significant rise of mean fasting gastrin to $36 \cdot 7 \pm 7 \cdot 3 \mathrm{pmol} / 1 \quad(\mathrm{p}<0 \cdot 01)$. One week after stopping treatment with omeprazole mean fasting plasma gastrin concentration was $18.9 \pm 4.4 \mathrm{pmol} / \mathrm{l}$ which is significantly higher than before treatment $(p<0 \cdot 001)$. Eight weeks after cessation of

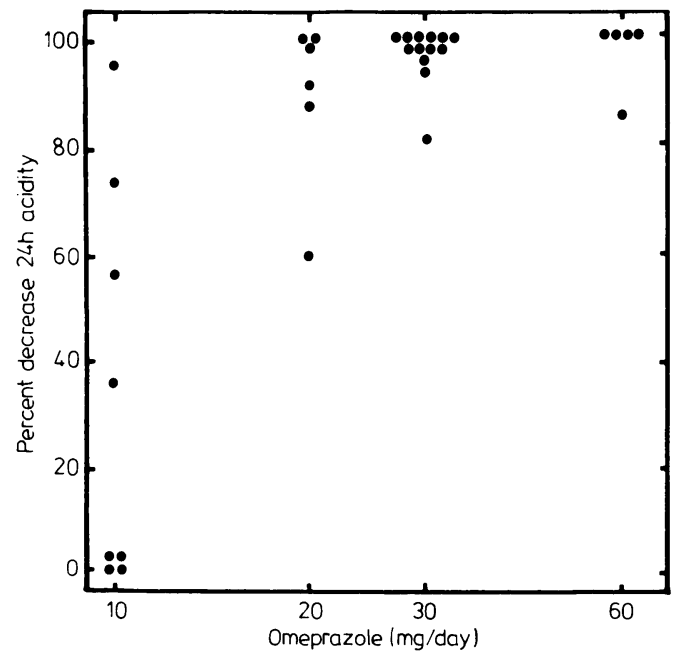

Fig. 2 Percentage decrease of 24 hour intragastric acidity related to daily dose of oral omeprazole in nine duodenal ulcer patients. treatment, however, the mean fasting plasma gastrin concentration was $8 \cdot 0 \pm 3 \cdot 1 \mathrm{pmol} / \mathrm{l}$, which is not significantly different to the before treatment value $(\mathrm{p}<0 \cdot 1>0 \cdot 05)$.

Figure 6 shows the total postprandial plasma gastrin responses in the six patients who received treatment with omeprazole 10,20 , and $30 \mathrm{mg} /$ day. Compared with the before treatment values, there was a significant rise of fasting plasma gastrin concentration during each regimen $(10 \mathrm{mg} \mathrm{p}<0.05$ $20 \mathrm{mg} \mathrm{p}<0.01 ; 30 \mathrm{mg} \mathrm{p}<0.001)$. These rises of fasting plasma gastrin concentration were reflected by raised total postprandial gastrin values, but there was no significant change in the postprandial integrated (incremental) gastrin response.

\section{PLASMA OMEPRAZOLE}

After all doses of oral omeprazole there was considerable variation in the timing and level of the peak plasma omeprazole concentration. This variation is shown by the concentrations seen in eight patients after one week of treatment with omeprazole $30 \mathrm{mg} /$ day (Fig. 7).

The area under the plasma omeprazole concentration/time curve (AUC) was related to the dose of omeprazole (Fig. 8), but the relationship was non-linear. Mean AUC increased 3.8-fold (range $1 \cdot 9-5 \cdot 1, \mathrm{n}=5$ ) when the dose increased from $30 \mathrm{mg}$ to $60 \mathrm{mg} /$ day. In three patients the mean AUC did not change significantly between the seventh and fourteenth doses of omeprazole $30 \mathrm{mg} \mathrm{(3.6} \mathrm{to} 3.3$ $\mu \mathrm{mol} / \mathrm{h} / \mathrm{l}$, respectively), the AUC was also related to the percentage decrease of mean 24 hour intragastric $\mathrm{H}^{+}$activity (Fig. 9). 
Fig. 3 Mean hourly intragastric $\mathrm{H}^{+}$activity in nine duodenal ulcer patients before, and one week after. Fourteen days of treatment with omeprazole 30-60 mg/day.

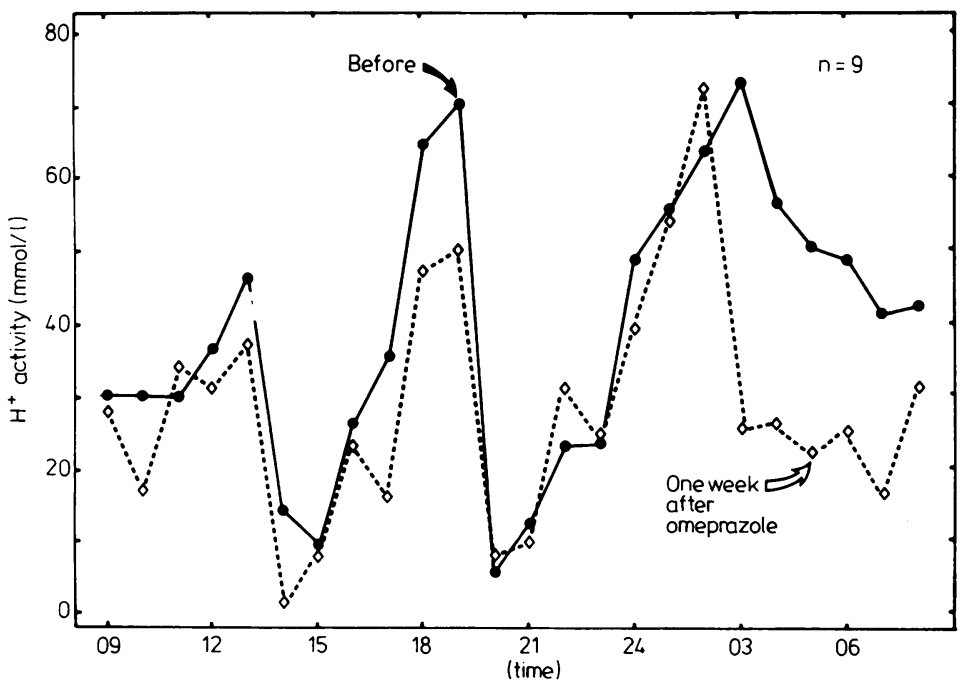

decrease of 24 hour intragastric acidity, the optimal dose of omeprazole is $30 \mathrm{mg} /$ day. Increasing the dose of oral omeprazole from 10 to $30 \mathrm{mg} /$ day caused a progressive decrease of 24 hour intragastric acidity. After seven days of treatment, omeprazole $30 \mathrm{mg} /$ day caused a $97 \%$ decrease of 24 hour intragastric acidity, with virtual anacidity from midday to midnight (Fig. 1). No further significant decrease of acidity was observed when the same dose was continued for an additional seven days, nor when the dose of omeprazole was doubled to 60 $\mathrm{mg} / \mathrm{day}$.

The results of this study show that, for a maximal

Fig. 4 Mean hourly intragastric $\mathrm{H}^{+}$activity in nine duodenal ulcer patients before, and eight weeks after, 14 days of treatment with omeprazole 30-60 mg/day.

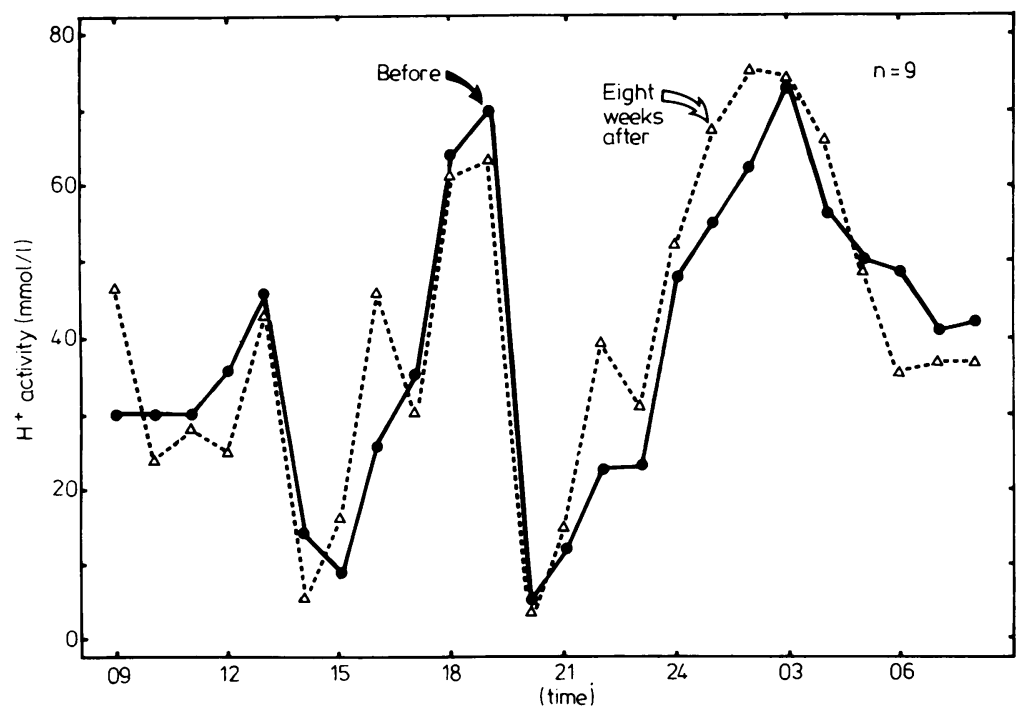


Fig. 5 Fasting plasma gastrin concentration in nine duodenal ulcer patients before, during and after 14 days of treatment with omeprazole $30-60 \mathrm{mg} /$ day.

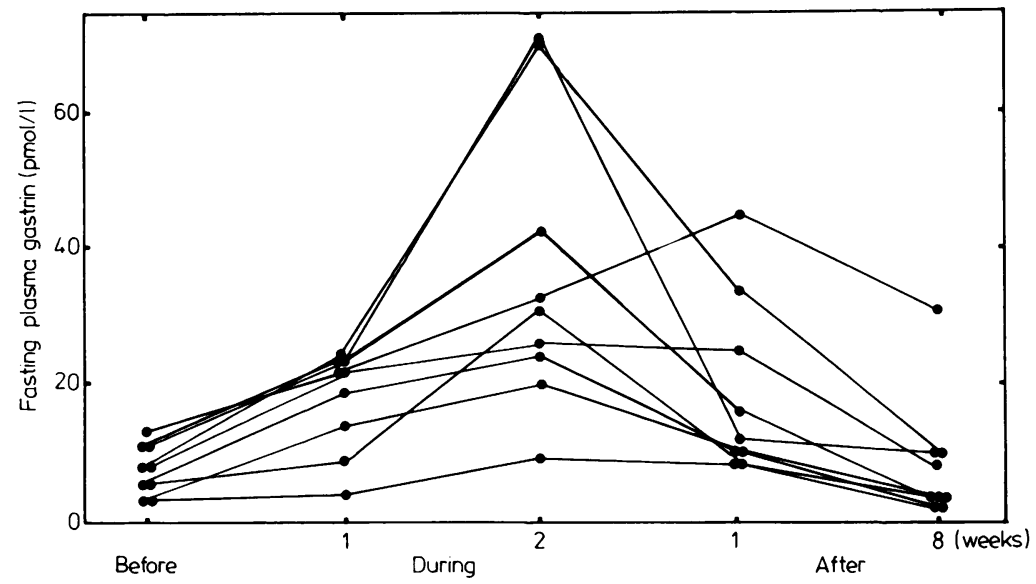

Omeprazole $20 \mathrm{mg} /$ day caused a $90 \%$ decrease of mean 24 hour intragastric acidity. Not only was more acid present in the stomach during the morning a and the night than with omeprazole 30 $\mathrm{mg} /$ day, however, but there was also a return of acid in the early evening. Omeprazole $20 \mathrm{mg} /$ day caused a more profound and consistent decrease of acidity throughout the 24 hours (Fig. 1) than that observed

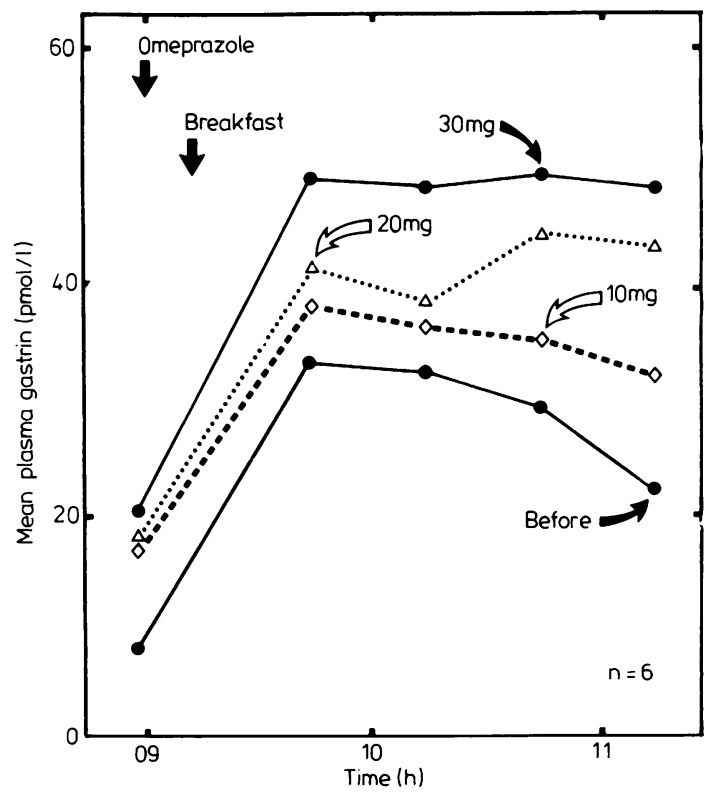

Fig. 6 Total postprandial gastrin responses in six patients before and during treatment with omeprazole 10, 20 and 30 $\mathrm{mg} /$ day. Seventh dose of omeprazole taken at 0900 hours; breakfast 0915 hours.

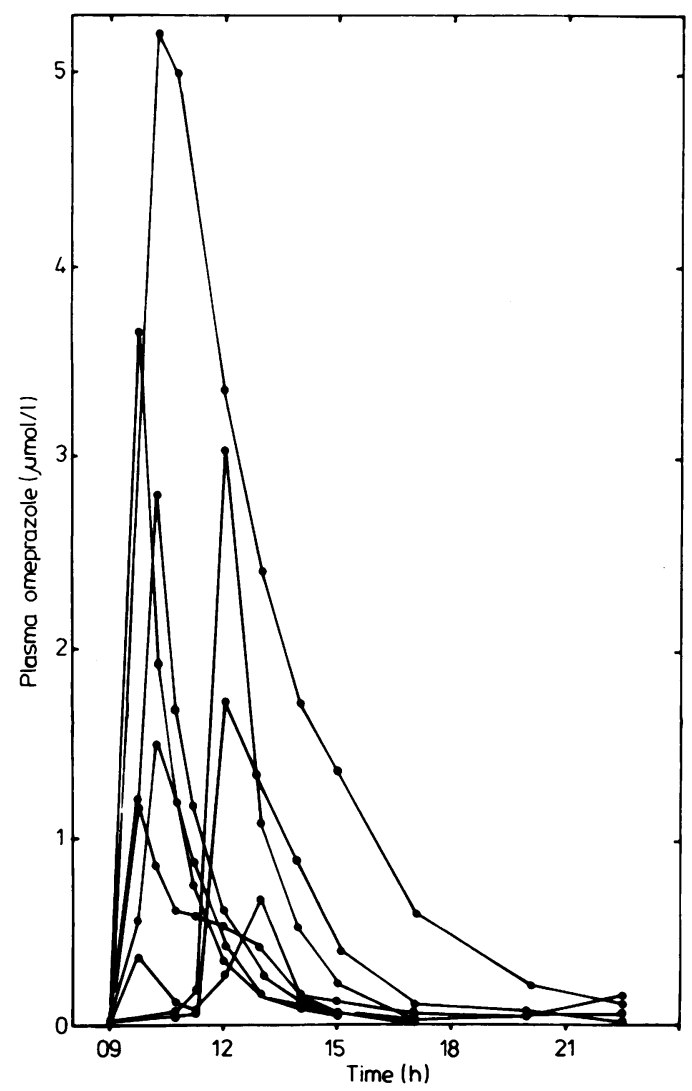

Fig. 7 Plasma omeprazole concentrations in eight patients after seventh dose of omeprazole $30 \mathrm{mg} /$ day at 0900 hours. 


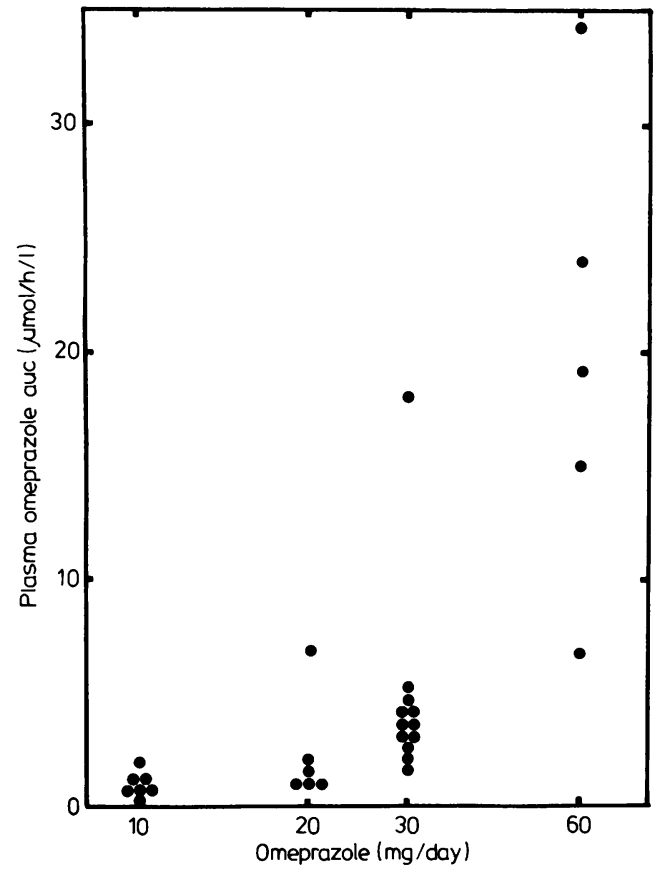

Fig. 8 Oral dose of omeprazole compared with area under plasma omeprazole concentration/time curve (AUC).

with either cimetidine or ranitidine in conventional dosage regimens. ${ }^{13}$ Omeprazole $20 \mathrm{mg} /$ day caused median 24 hour intragastric $\mathrm{pH}$ to rise from 1.4 to $5 \cdot 0$, whereas ranitidine $300 \mathrm{mg} /$ day or cimetidine $1 \mathrm{~g} /$ day caused median $\mathrm{pH}$ to rise from 1.4 to 1.7 and $2 \cdot 4$, respectively. ${ }^{14}$

Although omeprazole $10 \mathrm{mg} /$ day caused a statis- tically significant $37 \%$ decrease of mean 24 hour intragastric acidity, only four out of eight patients contributed to this decrease (Fig. 2). The remaining patients did not decrease their acidity with that dose of omeprazole. Because of the variation in response observed in this study, omeprazole $10 \mathrm{mg} /$ day may not be a suitable low dose for the maintenance therapy of peptic ulceration.

The consistent rises of fasting plasma gastrin observed during and after treatment with omeprazole probably reflect the prolonged decrease of intragastric acidity caused by the drug. There was a significant further rise of fasting plasma gastrin concentration between the seventh and fourteenth doses of omeprazole, however, when there was no further decrease of intragastric acidity. A significant rise of serum gastrin has been observed in duodenal ulcer patients during alkalinisation of the stomach using exogenous sodium bicarbonate solution. ${ }^{16}$ This change in gastrin was only observed when the intragastric environment was held at $\mathrm{pH} 7$ for five hours.

A rise in fasting plasma gastrin concentration has been observed during treatment with either cimetidine or ranitidine. ${ }^{17-23}$ The significant rise of fasting plasma gastrin during treatment with omeprazole may be owing not only to the drug's profound antisecretory effect, but also to its prolonged duration of activity. Postprandial plasma gastrin concentration may rise during cimetidine or ranitidine treatment, when intragastric acidity is not neutralised by intragastric titration with alkali. $^{24-26}$ Postprandial hypergastrinaemia during $\mathrm{H}_{2}$ blockade develops one to two hours after the meal, ${ }^{24} 25$ whereas there is a consistent rise in postprandial plasma gastrin during omeprazole treatment (Fig. 6), due to the rise of fasting plasma
Fig. 9 Area under plasma omeprazole concentration/time curve $(A U C)$ compared with percentage decrease of mean 24 hour intragastric acidity.

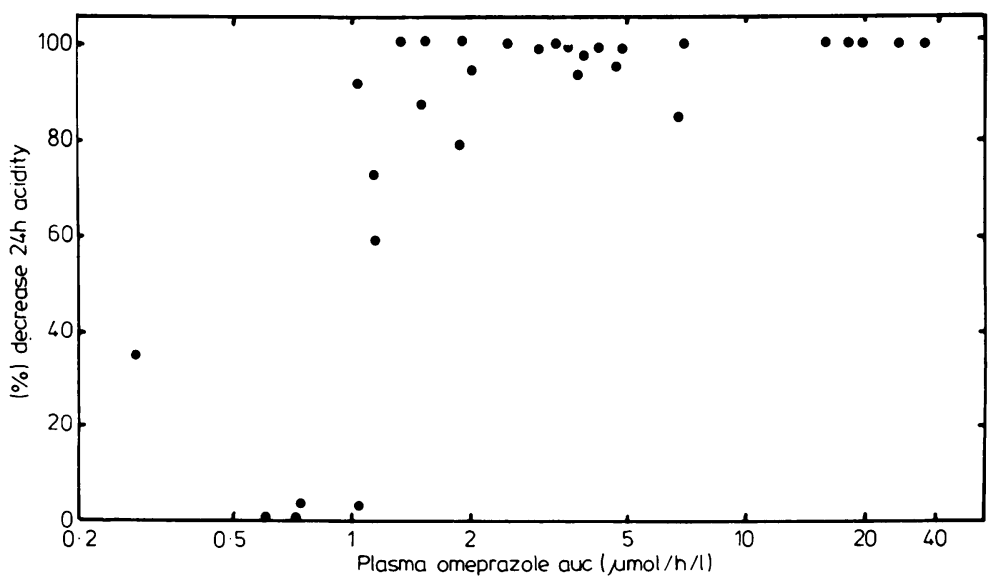


gastrin concentration.

The therapeutic advantages and disadvantages of the profound decrease of 24 hour intragastric acidity caused by omeprazole are unclear at the present. A dose-comparative study suggested that omeprazole $20 \mathrm{mg}$ or $60 \mathrm{mg} /$ day can provide rapid and complete healing of acute duodenal ulceration, ${ }^{27}$ but controlled studies are awaited. The hypergastrinaemia observed in this study could possibly promote parietal cell hyperplasia, with the risk of associated rebound hyperacidity after withdrawal of omeprazole treatment. Detailed studies of posttreatment intragastric acidity and acid secretion are necessary, as well as careful documentation of post-treatment ulcer relapse in controlled clinical studies. Prolonged anacidity may allow intragastric bacterial colonisation and proliferation, but this is unlikely to be of importance if the drug is used only for the acute treatment of peptic ulceration.

Omeprazole, taken as a capsule 15 minutes before breakfast, causes a sustained decrease of intragastric acidity, which persists after clearance of the drug from the plasma (Figs. 1 and 7). This continuation of omeprazole's antisecretory activity has been observed before, ${ }^{9}$ but its long duration is confirmed by the finding of a significant decrease of mean 24 hour intragastric acidity seven days after the last of 14 doses of omeprazole. The persisting decrease of intragastric acidity was seen throughout the 24 hour study, but was most marked during the basal secretion of the latter part of the night (Fig. 3). The mechanism of this prolonged inhibition is unclear, particularly as omeprazole-induced inhibition of acid secretion is rapidly reversible in isolated guinea pig parietal cells. ${ }^{8}$ Omeprazole's long duration of activity could prove to be a major therapeutic benefit, as control of intragastric acidity would be sustained despite minor lapses of compliance by a patient. Eight weeks after the last dose of omeprazole intragastric acidity had returned to the pretreatment level, showing recovery of normal gastric function.

The pattern of plasma omeprazole concentration was extremely variable after the oral administration of this preparation of the drug. As omeprazole is unstable in an acid environment, the drug was protected in this study by an enteric coating. The enteric coated granules of omeprazole appear to leave the stomach with either breakfast or morning coffee, causing peak concentrations in the plasma at 1000 or 1200 hours (Fig. 7). When omeprazole is taken in a water Methocel suspension, containing $8 \mathrm{mmol}$ sodium bicarbonate, there is rapid absorption with a peak plasma concentration of the drug at 30-40 minutes. The area under the plasma omeprazole concentration time curve is related to the oral dose of omeprazole, and also to the percentage decrease of 24 hour intragastric acidity (Figs. 8 and 9). Statistical analyses of these relationships are difficult because of insufficient middle-ofthe-range values with which to plot a full dose response curve. The relationship between dose of omeprazole and AUC was non-linear, as shown by nearly four-fold increases in AUC when the dose doubled from 30 to $60 \mathrm{mg} /$ day. This suggests that an excretory or metabolic pathway becomes saturated at this dose. It is therefore of importance that accumulation of the drug did not occur when patients took $30 \mathrm{mg} /$ day for two weeks.

In conclusion, omeprazole was well tolerated by these duodenal ulcer patients. No abnormality of liver function was observed. ${ }^{27} 28$ This study shows that omeprazole $30 \mathrm{mg} /$ day is the optimal dose for a maximal decrease of 24 hour intragastric acidity in duodenal ulcer patients. Double-blind studies are required to compare the therapeutic activity of this potent drug with the conventional medical treatment of peptic ulceration.

Sister Sandra Masters and Staff Nurse Janet Jeal provided enthusiastic assistance throughout these studies. Miss Julia Semus provided secretarial support for the whole investigation. Plasma gastrin was measured by Professor S R Bloom's Laboratory, Hammersmith Hospital, London, and plasma omeprazole was measured by A B Hassle, Molndal, Sweden. Omeprazole capsules and financial support were supplied by Astra Pharmaceuticals Ltd, St Albans, England.

\section{References}

1 Olbe L, Haglund U, Leth R et al. Effects of substituted benzimidazole (H149/94) on gastric acid secretion in humans. Gastroenterology 1982; 83: 193-8.

2 Sachs G, Chang HH, Rabon E, Schackman R, Lewin M, Saccomani G. A non-electrogenic $\mathrm{H}^{+}$pump in plasma membranes of Hog stomach. J Biol Chem 1976; 251: 7690-8.

3 Saccomani G, Helander HF, Crago S, Chang HH, Dailey DW, Sachs G. Characterisation of gastric mucosal membranes. J Cell Biology 1979; 83: 271-83.

4 Fellenius E, Berglindh T, Sachs G et al. Substituted benzimidazoles inhibit acid secretion by blocking $\left(\mathrm{H}^{+} \mathrm{K}^{+}\right)$ATPase. Nature 1981; 290: 150-61.

5 Fellenius E, Berglindh T. Brandstrom A et al. The inhibitory action of substituted benzimidazoles on isolated oxyntic glands and $\mathrm{H}^{+} \mathrm{K}^{+}$ATPase. In: Schultz I, Sachs G, Forte JG, Ullrich KJ eds. Hydrogen ion transport in epithelia. Amsterdam: Elsevier/North Holland Press, 1980: 193-202.

6 Fellenius E, Elander B, Wallmark B. Helander HF, 
Berglindh T. Inhibition of acid secretion in isolated gastric glands by substituted benzimidazoles. Am J Physiol 1982; 243: G505-10.

7 Wallmark B, Sach G, Mardh S, Fellenius E. Inhibition of gastric $\mathrm{H}^{+} \mathrm{K}^{+}$ATPase by the substituted benzimidazole picoprazole. Biochem Biophys Acta 1983; 728: $31-8$.

8 Sewing KF, Harms P, Schultz G, Hannemann H. Effect of substituted benzimidazoles on acid secretion in isolated and enriched guinea pig parietal cells. Gut 1983; 24: 557-60.

9 Lind T, Cederberg C, Ekenved G, Haglund U, Olbe L. Effect of omeprazole - a gastric proton pump inhibitor - on pentagastrin stimulated acid secretion in man. Gut 1983; 24: 270-6.

10 Pounder RE, Williams JG, Milton-Thompson GJ, Misiewicz JJ. 24 hour control of intragastric acidity by cimetidine in duodenal ulcer patients. Lancet 1975; 2: 1069-72.

11 Pounder RE, Williams JG, Milton-Thompson GJ, Misiewicz JJ. Effect of cimetidine on 24 hour intragastric acidity in normal subjects. Gut 1976; 17: 133-8.

12 Pounder RE, Vincent $\mathrm{SH}$, Hunt $\mathrm{RH}$, MiltonThompson GJ, Misiewicz JJ. 24 hour intragastric acidity and nocturnal acid secretion in patients with duodenal ulcer during oral administration of cimetidine and atropine. Gut 1977; 18: 85-90.

13 Walt RP, Male PJ, Rawlings J, Hunt R, MiltonThompson GJ, Misiewicz JJ. Comparison of the effects of ranitidine, cimetidine and placebo on the 24 hour intragastric acidity and nocturnal acid secretion in patients with duodenal ulcer. Gut 1981; 22: 49-54.

14 Walt RP, Gomes M de FA, Wood EC, Logan LH, Pounder RE. Effect of daily oral omeprazole on 24 hour intragastric acidity. $\mathrm{Br}$ Med $J$ 1983; 287: 12-14.

15 Bryant MG, Adrian TE. Gastrin. In: Bloom SR, Long $\mathrm{RG}$, eds. Radioimmunoassay of gut regulatory peptides. London: Saunders, 1982: 51-9.

16 Peters MN, Feldman M, Walsh JH, Richardson CT. Effect of gastric alkalinization on serum gastrin concentrations in humans. Gastroenterology 1983; 85: 35-9.

17 Bank S, Barbezat GO, Vinik AI, Walter F, Helman CA. Cimetidine and serum gastrin levels in man. In: Burland WL, Simkins MA, eds. Cimetidine: proceedings of the second international symposium on histamine $\mathrm{H}_{2}$-receptor antagonists. Amsterdam: Excerpta Medica, 1977: 155-62.

18 Spence RW, Celestin LR, McCormick DA, Owens CJ. The effect of three months treatment with cimetidine on basal and 'oxo' stimulated serum gastrin. In:
Burland WL, Simkins MA, eds. Cimetidine: proceedings of the second international symposium on histamine $\mathrm{H}_{2}$-receptor antagonists. Amsterdam: Excerpta Medica, 1977: 163-74.

19 Hansky J, Stern AI, Korman MG, Waugh J. Effects of long-term cimetidine on serum gastrin in duodenal ulcer. In: Dig Dis Sci 1979; 24: 468-70.

20 Mohammed R, Holden RJ, Hearns JB, McKibben BM, Buchanan KD, Crean GP. Effects of eight weeks' continuous treatment with oral ranitidine and cimetidine on gastric acid secretion, pepsin secretion, and fasting serum gastrin. Gut 1983; 24: 61-6.

21 Giacosa A, Cheli R, Molinari F, Parodi MC. Comparison between ranitidine, cimetidine, pirenzepine and placebo in the short term treatment of duodenal ulcer. Scand J Gastroenterol 1982; 17: suppl 72: 215-9.

22 Bianchi Porro G, Petrillo M, Lazzaroni M. Ranitidine in the short-term treatment of duodenal ulcer: a multicentre endoscopic double-blind trial. In: Misiewicz JJ, Wormsley KG, eds. The clinical use of ranitidine. Oxford: Medicine Publishing Foundation, 1982: $136-42$.

23 Stage JG, Friis J, Nielsen OV. Ranitidine treated of post-operative recurrent ulcers. In: Misiewicz JJ, Wormsley KG, eds. The clinical use of ranitidine. Oxford: Medicine Publishing Foundation, 1982: 27580.

24 Richardson CT, Walsh JH, Hicks MI. The effect of cimetidine, a new histamine $\mathrm{H}_{2}$-receptor antagonist, on meal-stimulated gastric acid secretion, serum gastrin, and gastric emptying in patients with duodenal ulcer. Gastroenterology 1976; 71: 19-23.

25 Heading RC, Logan RFA, McLoughlin GP, Lidgard G, Forrest JAH. Effect of cimetidine on gastric emptying. In: Burland WL, Simkins MA, eds. Cimetidine: proceedings of the second international symposium on histamine $\mathrm{H}_{2}$-receptor antagonists. Amsterdam: Excerpta Medica 1977; 145-52.

26 Sherbanuik R. Wensel R, Trautman A et al. Ranitidine in the short-term management of symptomatic gastrooesphageal reflux. In: Misiewicz JJ, Wormsley KG, eds. The clinical use of ranitidine. Oxford: Medicine Publishing Foundation, 1982: 283-92.

27 Gustavsson S, Adami H, Loof L, Myberg A, Nyren O. Rapid healing of duodenal ulcers with omeprazole: double-blind dose-comparitive trial. Lancet 1983; 2: $124-5$.

28 Sharma BK, Santana IA, Walt RP, Pounder RE. Omeprazole and liver function tests. Lancet 1983; 2: 346. 